\title{
Editorial
}

http://dx.doi.org/10.14483/22487085.12379

\section{Exploring oral discourse development in the efl classroom: perspectives from Ecuador, Honduras, Chile $\varepsilon$ Colombia}

Educating learners of English as a second/foreign/additional language to speak is a complex social practice. Speaking in another language involves a range of processes that go from successfully handling new muscular movements to developing and consolidating an individual, yet social, voice in that language. This voice deals with the projected identity the learner deploys when engaging in meaningful interactions, which is constantly being negotiated in every use of the language. For Ortiz-Medina in this issue, "the construction of identities and, particularly, the ways in which English language learners position themselves and others are determined by how they interact in the power networks of the classroom" (p.252). She investigated how young adult learners of English constructed their identities as speakers of English through their positioning in oral tasks in an English class.

This issue of the CALJ presents a collection of articles by national and international authors with an emphasis on oral skills development in the English classroom at schools and universities. The studies include an immersion program to develop students' language proficiency through meaningful language use in a bilingual school in Honduras; studying how classroom interaction occurs in ELTE undergraduate programs and how much of it truly achieves pedagogical and interactional goals; a qualitative study of neologisms used by women and men in Spanish to understand how language speakers adapt to social changes; a discourse analysis comparison of essays and their corresponding oral presentation transcriptions; and a quasi-experimental research aimed to improve learners' oral production achievements through a direct instruction period (DIP) of memory and social learning strategies.

A field that needs to be further explored is the use of virtual reality software to create scenarios that can model natural interactions in the second language in contexts where that is not possible. Sanchez $\mathcal{E}$ Chavarro, in this issue, report the results of an action research project that describes content-subject teachers' EFL oral behavior when blended learning was implemented in a professional development course. They found that although blended learning influenced participants' oral production, EFL oral skill behavior relates to the use of vocabulary, use of body language, pronunciation and intonation patterns, production of chunks of language, monitoring oral production and, motivation and engagement. These are some of the problems that modeling natural interactions face and collaborative work between virtual platform designers and language educators are crucial to advance in this area.

In a world where English is an international language of communications, speaking is no longer associated to traditional accents as British, RP or American, but to the particular micro exchanges in which the learner constructs her repertoire of interlanguage possibilities as she negotiates the meanings to be communicated. A political discussion taking place in the fields of ELT and AL is about the status of English teachers as native or non-native speakers of English. Llurda (2004) claims that the international status of English makes it a truly intercultural language which may be used in a variety of contexts for a variety of purposes. However, the preference for native speaker teachers of English (NS) over Non-native speakers (NNS) to work in public and private schools in Latin American countries places teachers at a disadvantage and "increases the loss of public trust in local teachers and in university-based programs that train English teachers" (Llurda E González, 2016:104).

A final contribution in this issue is a pedagogical reflection article that describes key features of CLIL present in instruction with elementary school students' native speakers of Finnish learning English. The author used an observation tool for effective CLIL teaching that was 
chosen as the starting point and was complemented with three additional fields that were not markedly included in the original model: cultural aspects, affect, and assessment.

The papers included in this issue point to key problems that language educators in Latin America are tackling: learners' construction of a voice of their own in the additional language, the challenge of modelling naturally-occurring verbal exchanges in virtual platforms, the myth of the native speaking teacher to teach English as an international language of communications in a globalized world, and the increasing need to incorporate cultural and affective variables in English language education.

\section{References}

González, A. E Llurda, E. (2016). Bilingualism and globalization in Latin America: fertile ground for native-speakerism. In F. Copland, S. Garton, \& S. Mann. (Eds.). LETs and NESTs: Voices, Views and Vignettes. London: British Council.

Llurda, E. (2004). Non-native-speaker teachers and English as an International Language

International Journal of Applied Linguistics, 14, 3. Pp. 314-323.

Ortiz, J. (2017). Shaping your Identity as a Speaker of English: The Struggles of a Beginner Language Learner. Colomb. appl. linguist. j., 20(1), pp. 250-262.

Sánchez N. \& Chavarro S. (2017). EFL Oral Skills Behavior when Implementing Blended Learning in a Content-Subject Teachers' Professional Development Course. Colomb. appl. linguist. j., 19(2), pp. 263-276.

Amparo Clavijo Olarte PhD

Editor 